\title{
Pengaruh Penggunaan Media Video Terhadap Peningkatan Pemahaman Konsep Suhu dan Kalor Pada Siswa Kelas X Man 1 Palu.
}

\author{
Puput Istiqomah, I Komang Werdhiana, dan Unggul Wahyono \\ Puputajach23@yahoo.com \\ Program Studi Pendidikan Fisika FKIP Universitas Tadulako \\ Jl. Soekarno Hatta Km. 9 Kampus Bumi Tadulako Tondo Palu - Sulawesi Tengah
}

\begin{abstract}
Abstrak - Penelitian ini bertujuan untuk mengetahui ada tidaknya pengaruh penggunaan media video terhadap peningkatan pemahaman konsep suhu dan kalor pada siswa kelas X MAN 1 Palu. Jenis penelitian yang digunakan adalah "Quasi-Eksperimental" dengan desain "Equivalent Control Group Design". Sampel penelitian yaitu kelas X MIA 2 sebagai kelas eksperimen dan kelas X MIA 3 sebagai kelas kontrol. Instrumen yang digunakan berupa tes pemahaman konsep dalam bentuk essay tes. Berdasarkan hasil pengolahan data, untuk kelas eksperimen diperoleh rerata skor pre-test adalah 39,31 dengan standar deviasi 10,15 dan rerata skor post-test adalah 61,90 dengan standar deviasi 12,52. Sedangkan untuk kelas kontrol diperoleh rerata skor pretest adalah 27,04 dengan standar deviasi 9,59 dan rerata skor post-test adalah 41,48 dengan standar deviasi 9,84. Berdasarkan hasil pengujian $\mathrm{N}$-Gain untuk kelas eksperimen berada berada dalam kategori sedang dengan nilai $\mathrm{N}$-Gain sebesar 38,00\% dan untuk kelas kontrol berada dalam kategori rendah dengan nilai $\mathrm{N}-\mathrm{Gain}$ sebesar $19 \%$. Berdasarkan hasil pengujian hipotesis diperoleh nilai $t_{\text {hitung }}>t_{\text {tabel }}(6,75>1,67)$. Hal ini berarti $\mathrm{H}_{1}$ diterima dan $\mathrm{H}_{0}$ ditolak. Dengan demikian dapat dinyatakan bahwa ada pengaruh penggunaan media video terhadap peningkatan pemahaman konsep suhu dan kalor pada siswa kelas X MAN 1 Palu.
\end{abstract}

Kata Kunci : Pemahaman Konsep Fisika, Media Video.

\section{PENDAHULUAN}

Masalah utama pada pendidikan formal adalah masih rendahnya daya serap peserta didik. Pelajaran Fisika dikenal sebagai matapelajaran yang kurang disukai siswa. Kecenderungan ini berawal dari pengalaman belajar mereka menemukan kenyataan bahwa pelajaran Fisika adalah pelajaran berat yang serius dan tidak jauh dari persoalan konsep, pemahaman konsep penyelesaian soal-soal rumit melalui pendekatan matematis. Selain itu keterbatasan waktu untuk melakukan praktikum membuat siswa sangat sulit untuk memahami materi Fisika[1]. Penyampaian materi dalam pembelajaran fisika yang masih berpusat pada guru dan siswa yang hanya menghafal materi akan membuat siswa cepat lupa dengan materi yang diberikan serta menyebabkan proses berfikir siswa dalam bidang kognitif berkurang[2].

Pembelajaran fisika pada umumnya dilakukan oleh guru dengan menggunakan metode konvensional, tanpa melibatkan penggunaan media pembelajaran yang kaya visualisasi. Hal ini menyebabkan siswa tidak banyak terlibat dalam proses pengkonstruksian suatu konsep, melainkan tidak lebih dari sekedar mendengar dan menghafalkan konsep materi yang diajarkan[3].
Tercapainya tujuan pendidikan tidak terlepas dari adanya pengembangan dibidang pendidikan antara lain proses pembelajaran, media pembelajaran, pengadaan dan pengelolaan sarana dan prasarana. Berkaitan dengan pengembangan pendidikan tersebut, seorang guru dituntut agar memiliki pengetahuan mengenai inovasi dalam pembelajaran. Inovasi tersebut dimaksudkan agar kegiatan belajar mengajar lebih baik dan lebih menarik, sehingga dalam proses pembelajaran peran guru sangat penting dalam melaksanakan kegiatan belajar mengajar[4]. Media pembelajaran seperti gambar $[5,6]$ dan video [7] dapat meningkatkan hasil belajar dan motivasi siswa.

Pembelajaran yang aktif dapat menimbulkan interaksi antar siswa dengan unsur-unsur dinamis dalam pembelajaran. Unsur dinamis yang dimaksud ditekankan pada penggunaan media dalam pembelajaran. Iwantara [8] tertarik untuk menerapkan media video youtube karena dapat menghadirkan sesuatu yang dapat dilihat dan didengar sehingga dapat memotivasi siswa dan memberikan pengalaman belajar. Hasil belajar siswa yang mengikuti pembelajaran menggunakan media rill dan media video youtube lebih unggul dibandingkan pembelajaran menggunakan media charta[9]. 
Penggunakan video dalam pembelajaran, dapat menjadi daya tarik dan mampu mempertahankan perhatian siswa selama video tersebut diputar sehingga menyebabkan hasil belajar siswa yang menggunakan video lebih unggul dibandingkan siswa yang menggunakan model pembelajaran konvensional[10].

Penggunaan media pembelajaran secara tepat dan bervariasi dapat mengatasi sikap pasif peserta didik yang sesuai akan menjadikan pembelajaran lebih menarik. Hal tersebut dapat didukung dengan memanfaatkan fasilitas pendidikan untuk menunjang kegiatan pembelajaran dengan memanfaatkan kemajuan tekonologi yang ada saat ini.

Agar proses pembelajaran dapat meningkatkan hasil belajar siswa, guru harus memilih pendekatan pembelajaran yang sesuai dengan tujuan dan materi pembelajaran. Salah satunya adalah pendekatan kontekstual menggunakan media video. Pendekatan kontekstual menggunakan media video mengakibatkan banyak aktifitas yang dilakukan oleh siswa selama video pembelajaran diputar, antara lain menanggapi pertanyaan guru berdasarkan video pembelajaran yang diputar, bertanya dan menyimpulkan materi[11].

Kelebihan media video dapat kapan saja dan dimana saja diputar oleh siswa, dengan syarat adanya media yang mendukung untuk menayangkan video tersebut. Selain itu media video juga dapat digunakan berulang-ulang kali dan media video dapat dimanfaatkan pada jangka waktu yang panjang dalam proses pembelajaran selama isi dari media tersebut masih relevan dengan materi yang ada[12].

Berdasarkan uraian di atas, maka dilaksanakannya penelitian tentang pengaruh penggunaan media video yang dimaksudkan dapat mengubah pola pembelajaran sehingga dapat melibatkan siswa lebih aktif dalam proses pembelajaran. Pembelajaran yang dimaksud adalah pembelajaran yang dapat berlangsung ilmiah, dimana siswa diharapkan untuk dapat bekerja dan mengalami sendiri apa yang dipelajarinya bukan hanya sekedar mendengar dan mencatat pengetahuan dari guru.

\section{METODE PENELITIAN}

Jenis penelitian yang digunakan adalah "Quasi-Eksperimental" dengan desain "Equivalent Control Group Design".

TABEL 1 DESAIN PENELITIAN

\begin{tabular}{cccc}
\hline Kelompok & Pretest & Perlakuan & Postest \\
\hline Eksperimen & $\mathrm{O}_{1}$ & $\mathrm{X}$ & $\mathrm{O}_{2}$ \\
Kontrol & $\mathrm{O}_{1}$ & - & $\mathrm{O}_{2}$ \\
\hline
\end{tabular}

Keterangan :
$\mathrm{O}_{1} \quad$ : Tes Awal (pre-test)

$\mathrm{O}_{2}$ : Tes Akhir (post-test)

$X$ : Perlakuan untuk kelompok eksperimen dengan menggunakan bantuan media video dalam pembelajaran

Populasi dalam penelitian kali ini adalah kelas X MIA 2 sebagai kelas eksperimen yang menggunakan media video dalam pembelajaran dan kelas X MIA 3 sebagai kelas kontrol yang menggunakan pembelajaran konvensional.

Instrumen yang digunakan terdiri dari rencana pelaksanaan pembelajaran (RPP), silabus, bahan ajar, LKS, video dan test pemahaman konsep. Tes ini digunakan untuk mengetahui pemahaman konsep Fisika pada kelas yang menjadi sampel penelitian. Tes dibuat dalam bentuk tes essay.

Video pembelajaran yang digunakan dalam penelitian disesuaikan dengan materi pembelajaran suhu dan kalor. Video yang digunakan didalam penelitian ini tidak seluruhnya dibuat sendiri oleh penulis, terdapat beberapa video yang di unduh di media sosial. Selain itu, kesulitan yang dihadapi oleh penulis dalam pembuatan video ini adalah dalam pengeditan video yang menggunakan beberapa aplikasi diantaranya adalah Format Factory dan alikasi Ulead Video 11 . Format factory digunakan untuk merubah ukuran video yang diunduh pada media social, karena tidak semua ukuran video bisa dimasukkan kedalam aplikasi Ulead Video 11. Selanjutnya, kesulitan yang dirasakan oleh penulis dalam pembuatan video ini adalah menggabungkan backsound, rekaman suara dan video lainnya, yaitu aplikasi yang tidak terlalu memungkinkan ukuran terlalu besar, sehingga terkadang didalam penyimpanan video yang telah selesai dibuat ini bisa memakan waktu kurang lebih 12 jam. Namun, beberapa kesulitan dalam pembuatan video ini penulis dapat hadapi berkat kesabaran dalam pembuatannya.

\section{HASIL DAN PEMBAHASAN}

Hasil Pretest

Pretest (tes awal) yang diberikan kepada siswa baik pada kelas eksperimen maupun kelas kontrol bertujuan untuk melihat apakah kedua kelas mempunyai kemampuan awal pemahaman konsep yang sama.

Uji Normalitas

Berdasarkan hasil uji normalitas pada Tabel 2 dibawah, diketahui nilai $x^{2}$ hitung $<x^{2}$ tabel atau $x^{2}$ hitung baik kelas eksperimen maupun kelas kontrol lebih kecil dibandingkan dengan nilai $x^{2}$ tabel. Dimana untuk kelas eksperimen $6,74<$ 
7,81 dan untuk kelas kontrol 2,43<7,81. Sesuai kriteria pengambilan keputusan, maka baik data dari kelas eksperimen maupun kelas kontrol keduanya berasal dari populasi yang terdistribusi normal.

TABEL 2 HASIL UJI NORMALITAS PRETEST PADA KELAS EKSPERIMEN DAN

\begin{tabular}{lcc} 
& \multicolumn{3}{c}{ KELAS KONTROL } \\
\cline { 2 - 3 } Uraian & \multicolumn{3}{c}{ Pretest } \\
\cline { 2 - 3 } & \multicolumn{3}{c}{ Eksperimen } & Kontrol \\
\hline Sampel & & 27 \\
$x^{2}$ hitung & 6,74 & 2,43 \\
$x^{2}$ tabel & 7,81 & 7,81 \\
Keterangan & \multicolumn{2}{c}{ Normal } \\
\hline
\end{tabular}

Uji Homogenitas

Pada pengujian homogenitas varians data dengan taraf signifikan 0,05 pada kelas eksperimen dan kelas kontrol, nilai Fhitung kurang dari nilai $F_{\text {tabel }}$ ( $F_{\text {hitung }}=1,12<$ Ftabel $=$ 1,90). Dengan kriteria pengujian $\mathrm{H}_{0}$ diterima jika Fhitung $\leq F_{\text {tabel. }}$ Dari Tabel 3 dapat dilihat bahwa nilai Fhitung berada pada daerah penerimaan $\mathrm{H}_{0}$ dengan demikian data tersebut menunjukkan kedua kelas yang dijadikan berasal dari populasi yang sama (homogen).

TABEL 3 HOMOGENITAS DUA VARIANS PRETEST KELAS EKSPERIMEN DAN KELAS KONTROL

\begin{tabular}{lcc}
\hline & \multicolumn{2}{c}{ Pretest } \\
\cline { 2 - 3 } Uraian & Eksperimen & Kontrol \\
\hline F & 1,12 & 1,12 \\
$F_{\text {tabel }}$ & 1,90 & 1,90 \\
\hline
\end{tabular}

\section{Uji Beda Dua Rerata}

Hasil perolehan skor rata-rata pretest dan post-test pemahaman konsep fisika dari kedua kelas dapat dilihat pada Gbr 1.

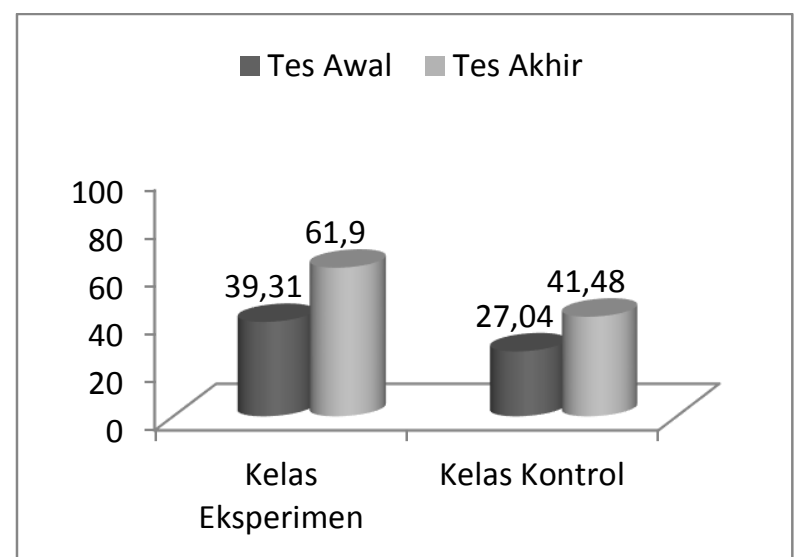

Gbr 1 Diagram Perolehan Skor Rata-Rata Pretest Dan PostTest Pemahaman Konsep Fisika.

Berdasarkan Gbr 1 dapat dilihat bahwa pretest baik kelas eksperimen maupun kelas kontrol memiliki skor rata-rata yang relatif sama. Pada post-test untuk kelas eksperimen dan kelas kontrol memiliki perbedaan skor ratarata yang relatif jauh yaitu pada kelas eksperimen sebesar 61,90 dengan standar deviasi 12,52 dan kelas kontrol sebesar 41,48 dengan standar deviasi 9,84.

Hasil Post-Test

Post-Test (tes akhir) yang diberikan kepada siswa baik pada kelas eksperimen maupun kelas kontrol bertujuan untuk melihat apakah kedua kelas mengalami peningkatan pemahaman konsep dari keadaan awal.

\section{Uji Hipotesis}

Berdasarkan hasil uji normalitas dan uji homogenitas yang telah dilakukan, diperoleh data yang berdistribusi normal dan homogen sehingga dapat dilanjutkan dengan uji hipotesis (satu pihak) dengan melihat bahwa kedua varians homogen dengan taraf signifikansi $a=$ 0,05 .

Hasil perolehan pengujian statistik data hasil kemampuan memecahkan masalah fisika antara kelas eksperimen dan kelas kontrol ditunjukkan pada Tabel 4.

TABEL 4 UJI SIGNIFIKANSI (SATU PIHAK) PADA KELAS EKSPERIMEN DAN

\begin{tabular}{cc} 
KELAS KONTROL & Post test \\
\hline Uraian & 5,61 \\
thitung & 1,67 \\
t tabel & Ditolak \\
$H_{0}$ & Diterima \\
$H_{1}$ &
\end{tabular}

Berdasarkan Tabel 4 Nilai thitung $>$ tabel atau $5,61>1,67$. Hal ini menunjukkan bahwa thitung berada diluar daerah penerimaan Ho. Dengan demikian $\mathrm{H}_{1}$ diterima dan $\mathrm{H}_{0}$ ditolak. Artinya bahwa pemahaman konsep siswa yang menggunakan media video lebih meningkat dari pemahaman konsep siswa yang mendapatkan pembelajaran konvensional.

\section{Uji N-Gain}

Hasil perhitungan skor N-Gain siswa kelas eksperimen sebesar 38,00 \% dan kelas kontrol sebesar 19,00 \%. Kelas eksperimen termasuk dalam kategori sedang, dimana G > 30 dan kelas kontrol termasuk dalam kategori rendah, dimana $\mathrm{G}<30$. Berdasarkan analisis data kedua kelas mengalami peningkatan. Peningkatan yang terjadi menunjukkan bahwa kelas eksperimen lebih besar peningkatannya dibandingkan kelas kontrol.

Adapun perbandingan $\mathrm{N}$-gain dari kedua kelas dapat dilihat pada Gbr 2. 


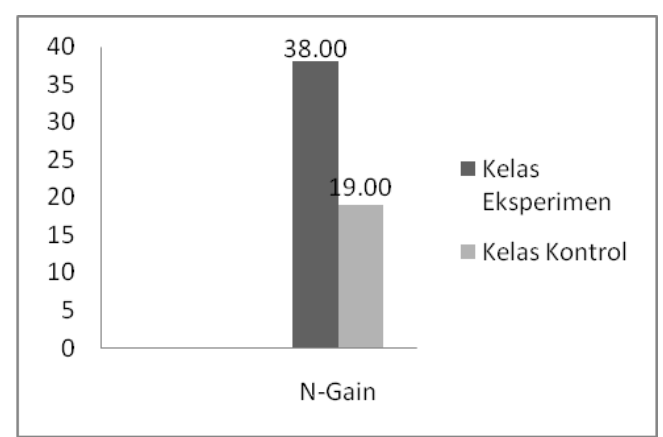

Gbr 2 Diagram Perbandingan N-Gain Kelas Eksperimen Dan Kelas Control.

Penelitian ini bertujuan untuk mengetahui ada tidaknya pengaruh penggunaan media video yang diterapkan pada kelas eksperimen dan model pembelajaran konvensional yang diterapkan pada kelas kontrol. Pada penelitian ini, Kegiatan pembelajaran dilakukan sebanyak 5 kali pertemuan terdiri dari 3 kali tatap muka dikelas dan 2 kali pertemuan untuk pretest dan posttest baik pada kelas eksperimen maupun kelas kontrol. Pada awal penelitian kedua kelas terlebih dahulu diberikan pretest. Tes awal (pre-test) digunakan untuk mengetahui kemampuan awal siswa sebelum diberikan perlakuan. Sedangkan tes akhir (post- test) diberikan untuk mengetahui peningkatan pemahaman konsep siswa setelah diberi perlakuan.

Analisis tahap awal dilakukan untuk mengetahui keadaan awal siswa. Nilai rata-rata tes awal (pretes) pemahaman konsep siswa pada kelas kontrol adalah 27,04 dengan standar deviasi adalah 9,59 dan kelas eksperimen 39,31 dengan standar deviasi adalah 10,15. Berdasarkan data tersebut kemudian dilakukan uji normalitas, uji homogenitas, uji N-Gain dan uji hipotesis.

Setelah diberi perlakuan menggunakan media video pada kelas eksperimen dan model pembelajaran konvensional pada kelas kontrol, maka kedua kelas mengalami peningkatan pemahaman konsep dari keadaan awal. Hal tersebut dapat dilihat melalui hasil analisis posttest. Nilai rata-rata posttest pemahaman konsep siswa pada kelas kontrol adalah 41,48 dengan standar deviasi adalah 9,84 dan kelas eksperimen adalah 61,90 dengan standar deviasi adalah 12,52. Berdasarkan hasil posttest pemahaman konsep siswa pada kelas eksperimen dan kelas kontrol sama-sama mengalami perubahan.

Secara kualitatif dengan menggunakan uji NGain, pada kelas kontrol yang menggunakan model pembelajaran konvensional memperoleh nilai N-Gain sebesar $19,00 \%$. Sedangkan pada kelas eksperimen yang menggunakan media video dalam pembelajaran memperoleh nilai $\mathrm{N}$ -
Gain sebesar 38,00\%. Secara kuantitatif, dengan menggunakan uji signifikan (uji t satu pihak), pada kelas ekspermen dan kelas kontrol memperolah nilai thitung lebih besar dari pada $t_{\text {tabel }}(5,61>1,67)$.

Berdasarkan hasil pengolahan data N-Gain dan uji t-satu pihak diatas, maka dapat dilihat bahwa peningkatan terjadi lebih besar pada kelas eksperimen dibandingkan dengan kelas kontrol. Hal ini dikarenakan pada kelas eksperimen menggunakan alat bantu media video sebagai media pembelajaran. Selain itu, peneliti merasa adanya media video yang hadir pada saat proses pembelajaran berlangsung, dapat membantu menyampaikan isi dan tujuan pembelajaran lebih cepat dibandingkan dengan kelas kontrol yang menggunakan model pembelajaran konvensional.

Dilihat dari nilai $\mathrm{N}$-Gain dan uji $t$ diatas menunjukkan bahwa penggunaan media video dalam pembelajaran dirasa lebih baik dan dapat meningkatkan pemahaman konsep siswa. Hasil penelitian ini didukung oleh Daryanto (2010) yang mengungkapkan bahwa manfaat penggunaan media video pembelajaran akan membuat pesan yang disampikan menjadi lebih menarik perhatian, perhatian inilah yang penting dalam proses belajar, karena adanya perhatian akan timbul rangsangan atau motivasi belajar dan dapat membuat anak didik berkonsentrasi.

Model pembelajaran yang menggunakan media video sebagai bantuan dalam penyampaian informasi pembelajaran dirasakan oleh peneliti mampu membuat siswa aktif, apalagi video yang ditampilkan dirancang semenarik mungkin namun masih tetap isi dari video tersebut mengacu pada isi materi pembelajaran yang ada. Salah satu keaktifan siswa yang terjadi didalam kelas adalah keinginan siswa bertanya setelah siswa mengamati video pembelajaran yang ditampilkan oleh guru. Selain itu, penyajian materi melalui media video dirasa sangat efektif karena kebanyakan siswa cepat merasa bosan ketika materi pembelajaran yang diberikan guru hanya dengan menggunakan metode ceramah seluruhnya.

Salah satu keunggulan penggunaan media video yaitu dapat diputar berulang-ulang kali dan dapat dimanfaatkan pada jangka waktu yang panjang dalam proses pembelajaran selama isi dari media tersebut masih relevan dengan materi yang ada.

$\mathrm{Hal}$ ini juga sesuai dengan penelitian Smaldino [13] menyatakan bahwa penampilan video yang dapat diulang sesuai keinginan membuat para siswa termotivasi untuk 
mengamati dan menganalisis fenomena dalam kehidupan sehari-hari.

Keunggulan penggunaan media video didalam pembelajaran yaitu dapat memperlihatkan beberapa aspek yang sulit dijelaskan secara langsung. Contohnya tentang pergerakan molekul. Berdasarkan hasil pengujian, siswa lebih mudah memahami materi pembelajaran apabila disajikan dalam bentuk video.

\section{KESIMPULAN}

Berdasarkan analisis data N-Gain diperoleh hasil bahwa pemahaman konsep siswa lebih baik pada kelas eksperimen dibandingkan kelas kontrol. Hal ini sesuai dengan perbedaan nilai $\mathrm{N}$-Gain terjadi lebih besar pada kelas eksperimen dibandingkan dengan kelas kontrol yaitu untuk kelas eksperimen 38,00 (kategori sedang) dan untuk kelas kontrol 19,00 (kategori rendah) sehingga dapat dinyatakan bahwa pemahaman konsep siswa yang menggunakan media video lebih unggul dibandingkan kelas kontrol yang menggunakan model pembelajaran konvensional.

\section{DAFTAR PUSTAKA}

[1] Yuliono, S.N. (2014). "Video Pembelajaran Berbasis Masalah Pada Materi Kalor Untuk Siswa Kelas VII". Jurnal Pendidikan Fisika. Vol. 1 No. 2 halaman 21.

[2] Yulianto, E. (2014). "Penerapan Model Pembelajaran POE(Predict-Observe-Explain) Untuk Meningkatkan Kemapuan Berfikir Kritis dan Kognitif Siswa SMP". Unnes Physics Education Journal. Tersedia : http//journal.unnes.ac.id/sju/index.php/upej.
[3] Sutarno, (2011). "Penggunaan Multimedia Interaktif Pada Pembelajaran Medan Magnet Untuk Meningkatkan Keterampilan Generik Sains Mahasiswa". jurnal exacta, vol. 9, 2011, halaman 61.

[4] Fechera, B. (2012). "Desain dan Implementasi Media Video Prinsip-prinsip Alat Ukur Listrik dan Elektronika". Skripsi UPI Bandung, Volume VIII, No. 2, September 2012 : 115-126.

[5] Apriani. (2016). "Upaya Meningkatkan Keterampilan Membaca Permulaan Melalui Penggunaan Media KataKata Bergambar Pada Siswa Kelas 1 SDN Uekambuno 2". Jurnal Kreatif Tadulako Online, Vol. 4 No. 4, 124135.

[6] Posia, Jamaluddin, dan Abduh H. H. (2016). "Penggunaan Media Gambar Untuk Meningkatkan Motivasi Belajar Siswa Dalam Pembelajaran IPS Siswa Kelas IV SD Negeri 6 Tolitoli". Jurnal Kreatif Tadulako Online, Vol. 4 No. 3. 83-94.

[7] Asri. (2016). "Meningkatkan Apresiasi Siswa Kelas VII SMPN 3 Labuan Dalam Menyimak Puisi Melalui Strategi Modeling dengan Menggunakan Media Video Rekaman Puisi". Jurnal Kreatif Tadulako Online, Vol. 4 No. 3. 262-269.

[8] Iwantara, W. (2014). "Pengaruh Penggunaan Media Video Youtube Dalam Pembelajaran IPA Terhadap Motivasi Belajar dan Pemahaman Konsep Siswa". eJournal Program Pascasarjana Universitas Pendidikan Ganesha, Program Studi IPA, Volume 4 Tahun 2014.

[9] Primafera, I. R. C. (2014). "Pengaruh Media AudioVisual (Video) Terhadap Hasil Belajar Siswa Kelas XI Pada Konsep Elastiisitas". Prosiding Seminar Nasional Pendidikan IPA FITK UIN Syarif Hidayatullah Jakarta, Jakarta 11 September 2014.

[10] Afifah, N. (2013). "Penerapan Pendekatan Kontekstual Menggunakan Media Video Untuk Meningkatkan Hasil Belajar Fisika Pada Kelas XI RPL 1 SMK N 8 Semarang". Seminar Nasional, $2^{\text {nd }}$ Lontar Physics Forum 2013.

[11] Sudirman, N. (1992). Ilmu Pendidikan. Bandung: Rosda Karya.

[12] Daryanto. (2010). Media Pembelajaran. Yogyakarta: Gava Media.

[13] Smaldino, S. et, a.I. (2011). Instructional Technology and Media for Learning. Jakarta: Kencana Prenado Group, Cet, I. 